\title{
Halosarpheia heteroguttulata sp.nov. from submerged wood in streams
}

\author{
S.W. Wong, K.D. Hyde, and E.B.G. Jones
}

\begin{abstract}
A new species of Halosarpheia, $H$. heteroguttulata, is described from wood submerged in streams and lakes in Australia, Brunei, Hong Kong, Mauritius, the Philippines. and South Africa. It differs from other species in the genus in ascospore dimensions, and consistently large guttule(s) in the apical cell, but many smaller guttules in the basal cell. The species is illustrated with light and scanning and transmission electron micrographs and compared with other Halosarpheia species.
\end{abstract}

Key words: appendage ontogeny. freshwater Ascomycete. Halosarpheia. taxonomy, ascospore ultrastructure.

Résumé : Les auteurs décrivent une nouvelle espèce d’Halosarpheia, l'H. heteroguttulata, récoltée sur du bois submergé dans des ruisseaux et des lacs de l'Australie, du Brunei, de Hong Kong. de l'île Maurice, des Philippines et de l'Afrique du sud. Il se distingue des autres espèces du genre par les dimensions des ascospores et la présence constante de grande(s) guttule(s) dans la cellule apicale, mais de plusieurs guttules plus petites dans la cellule basale. On illustre l'espèce à l'aide de micrographies photoniques et électroniques par balayage et transmission, et on la compare avec les autres espèces d'Halosarpheia.

Mots clés : ontogénie des appendices, ascomycètes d'eau douce, Halosarpheia, taxonomie, ultrastructure des ascospores.

[Traduit par la Rédaction]

\section{Introduction}

Halosarpheia Kohlm. \& E. Kohlm. (1977), typified by Halosarpheia fibrosa Kohlm. \& E. Kohlm., was originally described from wood submerged in the sea. The genus is characterized by mostly immersed, soft-walled ascomata: clavate, unitunicate, persistent, or deliquescent asci; and hyaline, one-septate, or multiseptate ascospores with filamentous polar appendages. The ascospore appendages are initially hamate but unfurl in water and form long, filamentous threads (Kohlmeyer and Kohlmeyer 1977; Shearer and Crane 1980). Although $H$. fibrosa is an obligate marine species, Jones (1995) has suggested that more marine genera may be found to have freshwater counterparts as knowledge of freshwater ascomycetes increases. A number of marine genera, including Halosarpheia, Aniptodera, and Nais, have recently been reported from freshwater habitats (Hyde 1992a, 1992b; Shearer 1993; Hsieh et al. 1995). Three species of Halosarpheia: H. aquatica Hyde (Hyde 1992b). $H$. aquadulcis Hsieh et al. (Hsieh et al. 1995), and $H$. lotica Shearer (Shearer 1984) have been described solely from freshwater habitats or estuarine regions. In this article, Halosarpheia heteroguttulata is described as a new species of freshwater ascomycete. The ascospores in this species possess appendages similar to those found in other species of

Received January 28, 1997.

S.W. Wong, K.D. Hyde, and E.B.G. Jones. Department of Ecology and Biodiversity, The University of Hong Kong. Pokfulam Road, Hong Kong.
Halosarpheia, but the mature ascospores differ in having an apical cell with one or two large guttules and a basal cell with numerous small guttules. The ultrastructure of the ascospores and their appendages is examined using scanning and transmission electron microscopy.

\section{Materials and methods}

Natural. decayed, and submerged wood from dicotyledonous plants was collected from Crystal Cascades in North Queensland, Australia; a river near the Kuala Belalong Field Studies Centre in Temburong. Brunei; Plover Cove Reservoir in New Territories. Hong Kong; the Black River in Mauritius; Natigbasan Creek in Impalutao. Mindanao, the Philippines; and the Palmiet River in Durban, South Africa. The wood was taken to the laboratory and incubated in plastic boxes containing moist tissue paper and periodically examined for fungal fruiting structures. Squash mounts of ascomata in water were prepared on glass slide and the face view of the ascomata. paraphyses, asci. and ascospores were examined and photographed using a Leitz Dialux 22EB interference microscope.

For scanning electron microscopy, a few drops of ascospore suspension were pipetted onto a polycarbonate membrane (Nucleopore) with pore size of $5 \mu \mathrm{m}$. The ascospores were allowed to settle for 5-10 min and then fixed in $2 \%(\mathrm{w} / \mathrm{v})$ aqueous osmium tetroxide overnight at $4^{\circ} \mathrm{C}$. Fixed material was dehydrated through a graded ethanol series from 10 to $90 \%$ (in $10 \%$ steps), then $95 \%$ and followed by three changes of absolute ethanol. Each of the above changes were for $15 \mathrm{~min}$. Dehydrated material was critical point dried using carbon dioxide and coated with gold-palladium. Material was examined in a Leica Cambridge Stereoscan 440 scanning electron microscope (SEM) operated at $20 \mathrm{kV}$. 
Figs. 1-6. Halosarpheia heteroguttulata. Interference contrast micrographs. Fig. 1. Ascoma with released ascospores. Scale bar $=10 \mu \mathrm{m}$. Figs. 2-6. Ascospores with a large guttule in the apical cell and numerous small guttules in the basal cell; and polar appendages. Scale bars $=10 \mu \mathrm{m}$.

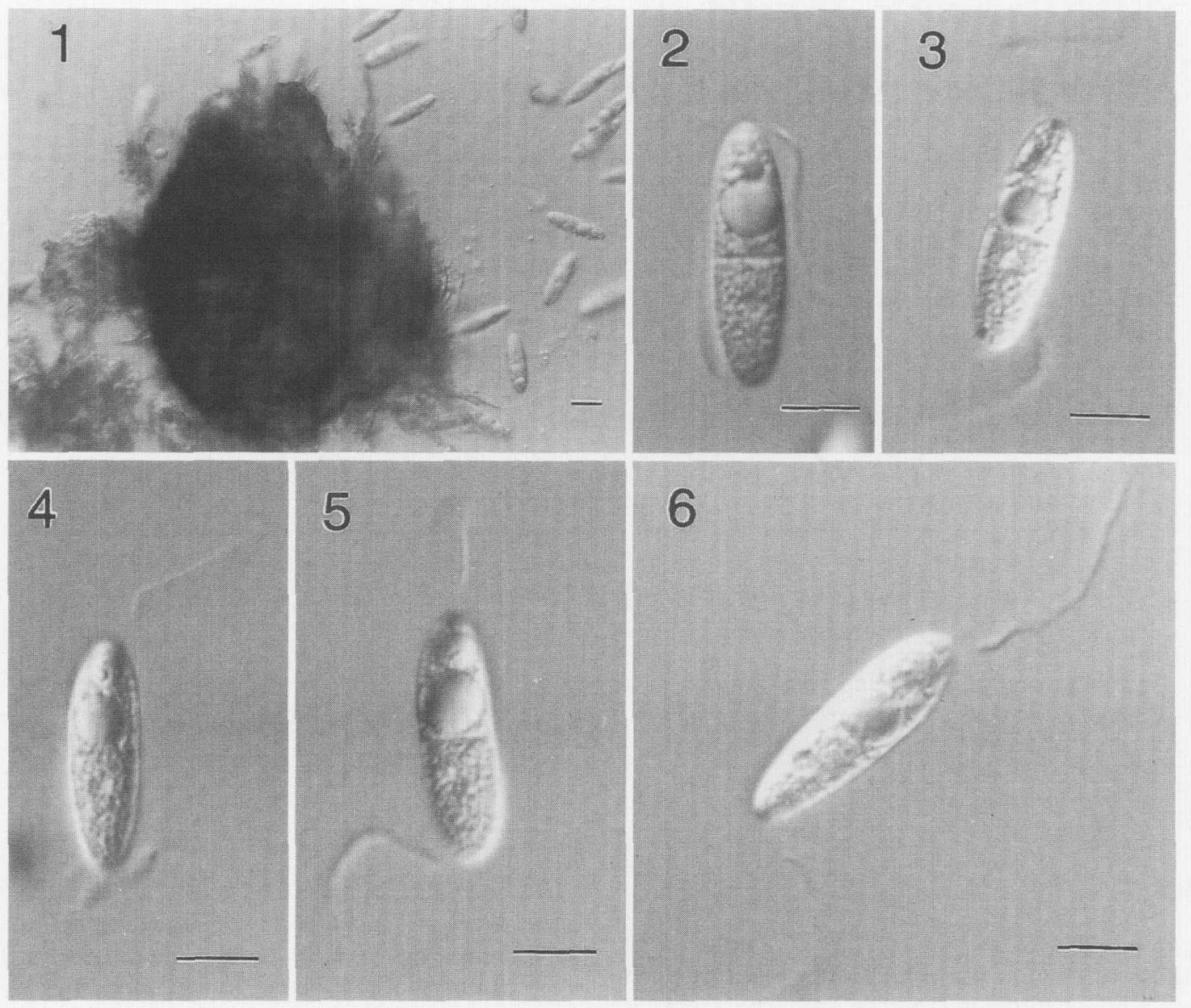

For transmission electron microscopy, an ascospore suspension was embedded in $2 \%(\mathrm{w} / \mathrm{v})$ ion agar and subsequently fixed in $4 \%$ $(\mathrm{v} / \mathrm{v})$ glutaraldehyde with added ruthenium red in $0.1 \mathrm{M}$ sodium cacodylate buffer at $\mathrm{pH} 7.2$ for $4 \mathrm{~h}$ at room temperature, and postfixed in $2 \%(\mathrm{w} / \mathrm{v})$ osmium tetroxide with added ruthenium red in $0.1 \mathrm{M}$ sodium cacodylate buffer at $\mathrm{pH} 7.2$ for overnight at $4^{\circ} \mathrm{C}$. The dehydration process was the same as described for scanning electron microscopy but the material was finally transferred to absolute acetone (three times, $15 \mathrm{~min}$ each). Fixed and dehydrated material was infiltrated by 25 and $50 \%$ Möllenhauer's resin (Möllenhauer 1964) in acetone for $36 \mathrm{~h}$ at each concentration, then 75 and $90 \%$ resin in acetone for $24 \mathrm{~h}$ at each concentration. The almost-infiltrated material was then transferred to a flat plastic mould with $100 \%$ resin and placed in a vacuum chamber at approximately $20 \mathrm{cmHg}(1 \mathrm{cmHg}=1333.22 \mathrm{~Pa})$ at room temperature for $4 \mathrm{~h}$. Finally. the embedded material was polymerized in an oven at $60^{\circ} \mathrm{C}$ for $3-5$ days. Ultrathin sections $(60-80 \mathrm{~nm})$ were obtained using a Diatome diamond knife. The sections were stained with lead citrate (Reynolds 1963) for 15 min and uranyl acetate solution for $30 \mathrm{~min}$. Finally, the specimens were examined using a JEOL 100SX transmission electron microscope (TEM) operated at $80 \mathrm{kV}$.

\section{Taxonomy}

Halosarpheia heteroguttulata S.W. Wong, K.D. Hyde \& E.B.G. Jones, sp.nov. (Figs. 1-16)
Ascomata 112-168 $\mu \mathrm{m}$ diametro, globosa vel subglobosa, immersa vel superficiales, nigra, membranecea, ostiolata, papillata. periphysata. Asci 8-spori, deliquescentes. Catenophyses praedita. Ascosporae 27-37 $\times 12.5-17.5 \mu \mathrm{m}$, ellipsoideae, hyalinae, 1-septatae, cellula apicali, 1-2 guttulatae, cellula basim multiguttulata praeditae.

Ascomata 112-168 $\mu \mathrm{m}$ diam., globose to subglobose, immersed or superficial, black, membraneous, ostiolate, papillate, periphysate. Neck long. Asci eight-spored, deliquescing early. Peridium 20-28 $\mu \mathrm{m}$ thick, composed of several layers of brown elongate cells. Catenophyses present. Ascospores 27-37 $\times$ 9-17.5 $\mu \mathrm{m}$, ellipsoidal, hyaline, one-septate, equally two-celled, apical cell with one or two large lipid guttule(s), basal cell with numerous small guttules, with bipolar, hamate, and highly coiled filamentous appendages that unfurl in water to form long strands, exosporium absent, appendage derived from the mesosporium through the discontinuities of episporium.

MODE OF LIFE: Saprobic.

HABITAT: On dicotyledonous wood submerged in freshwater.

KNOWY DISTRIBCTION: Australia, Brunei, Hong Kong, Mauritius, Philippines, South Africa. 
Figs. 7-10. Halosarpheia heteroguttulata. Ascospores. Scanning electron micrographs. Figs. 7-9. Ascospores showing the polar appendages, which are thread-like and sticky. Scale bars $=5 \mu \mathrm{m}$. Fig. 10. Higher magnifications showing the polar appendages emerged from the ascospore tip (arrowed). Scale bar $=1 \mu \mathrm{m}$.
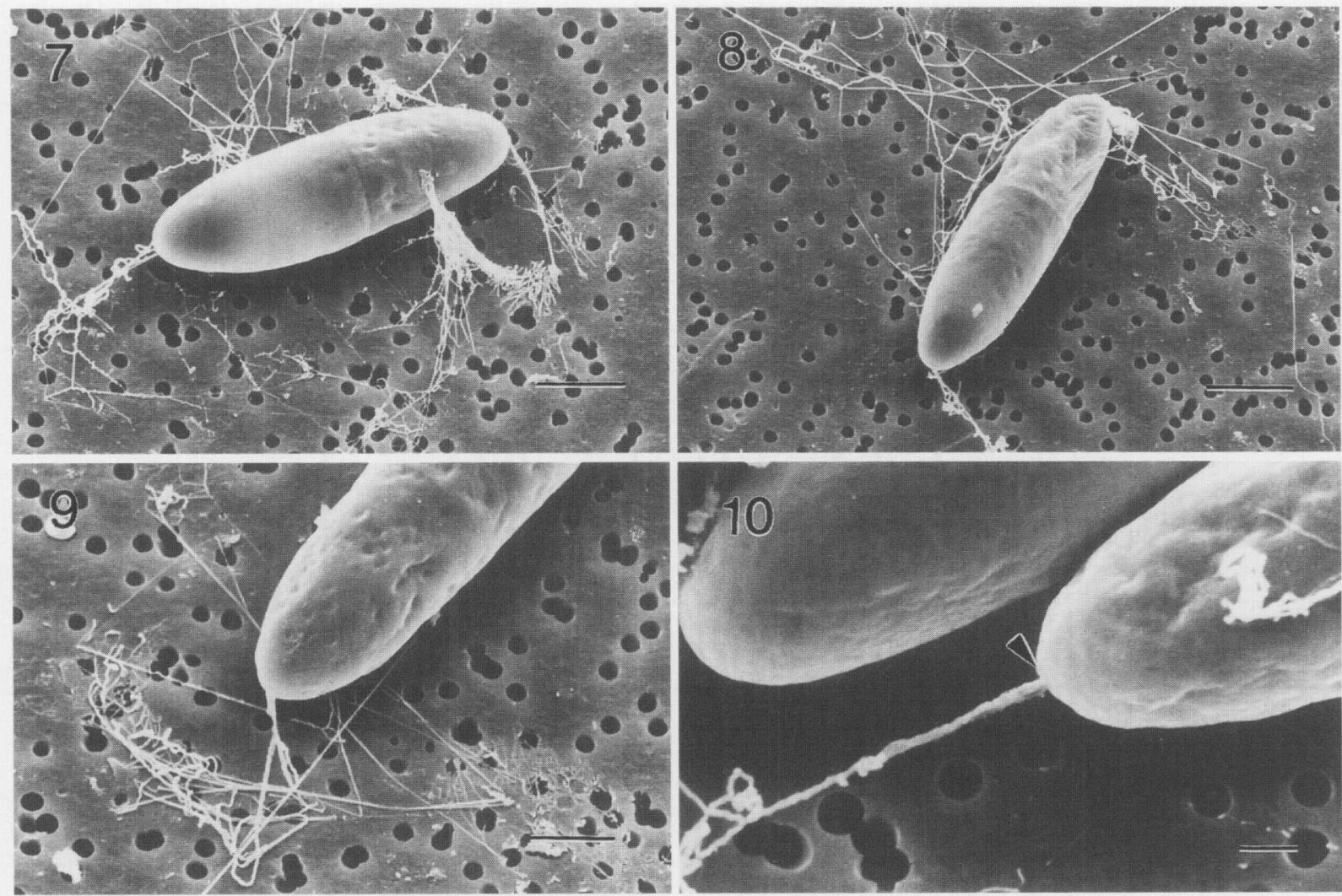

ETYMOLOGY: from the Latin hetero meaning half and guttulata meaning droplets, in reference to one cell having 1 or 2 large guttule(s) and the other having numerous smaller guttules.

HOLOTYPE: AUSTRALIA: North Queensland, Crystal Cascades, on submerged wood in small river, 28 Apr. 1996, T.M. \& K.D. Hyde (HKU(M)2806)

MATERIal. examined: AUSTRALIA: North Queensland, Crystal Cascades, on submerged wood in small river, 28 Apr. 1996, T.M. \& K.D. Hyde CC64 (HKU(M)2792); HONG KONG: Plover Cove Reservoir, on submerged wood, 15 Nov. 1996, M. Wong \& K.D. Hyde PC24 (HKU(M)3305), ibid. (HKU(M)3306); MAURITIUS: Black River, on submerged wood, August 1995, A. Poonyth \& K.D. Hyde (HKU(M)2383), ibid. (HKU(M)2385), ibid. (HKU(M)2393), ibid. (HKU(M)2394), ibid. (HKU(M)2422); SOUTH AFRICA: Durban, Palmiet River, on submerged wood, 15 Nov. 1994, T.S. Steinke \& K.D. Hyde (HKU(M)2175).

\section{Ultrastructure}

Mature ascospores of Halosarpheia heteroguttulata are ellipsoidal with bipolar, threadlike appendages that are highly coiled in a hamate complex adpressed to the ascospore wall (Figs. 11 and 12). Subsequently, the distal region of the coiled appendage separates from the ascospore wall and uncoils and forms threadlike appendages (Figs. 3-10). The uncoiled appendages are thin, sticky in nature, closely ad-

pressed to the polycarbonate membrane, and probably aid in the attachment of the ascospores to the substrate (Figs. 710). Threadlike appendages are connected at each pole of the ascospore where they are thicker in diameter (Figs. 9 and 10). The appendage comprises an electron-dense core surrounded by thick electron-transparent material (Figs. 15 and 16). Transverse sections of the coiled appendage indicates that it is a single filamentous appendage, which is folded and compact and closely adpressed to the electron-dense episporium.

Mature ascospores are one-septate with a different guttule deposition in each cell (Figs. 2-6 and 11). In the apical cell, one or two large guttule(s) are present, while in the basal cell, numerous small guttules occur.

The ascospore wall comprises two layers (Figs. 13 and 14): (i) a thin electron-dense episporium $(25-30 \mathrm{~nm})$ and (ii) a thick electron-transparent mesosporium (ca. $50 \mathrm{~nm}$ ). The mesosporium is more electron-dense towards the ascospore tip, although an electron-transparent zone is located at the ascospore tip (Figs. 13 and 14). The episporium is discontinuous in the area where the appendage emerges (Fig. 14). The appendage presumably derived from the mesosporium through this pore field of the episporium (Fig. 14).

\section{Discussion}

In $H$. heteroguttulata, ascospores have a characteristic guttule deposition. This arrangement of guttules is consistent in all our collections. The presence of guttules in the asco- 
Figs. 11-16. Halosarpheia heteroguttulata. Mature ascospores. Transmission electron micrographs. Fig. 11. Longitudinal section. The apical cell (AC) contains two large guttules and some smaller guttules. The basal cell (BC) contains numerous small guttules. Note the appendage (AP) adpressed to the ascospore wall near the ascospore tip. Scale bar $=1 \mu \mathrm{m}$. Fig. 12. Oblique longitudinal section of ascospore illustrating the appendage extending to the septum. The distal part of the coiled appendage (arrowed) is separated from the ascospore wall and uncoils into a filament. Scale bar $=1 \mu \mathrm{m}$. Fig. 13. Longitudinal section illustrating a coiled appendage (AP) adpressed to the ascospore wall. The mesosporium (M) is more electron-dense towards the ascospore tip with an electron-transparent zone (TZ) at the apex. Scale bar $=1 \mu \mathrm{m}$. Fig. 14. Ascospore tip showing the episporium (E) discontinuous or absent at the ascospore tip where the appendage emerges. Note the electron-transparent zone (TZ) in the mesosporium (M). Scale bar $=0.1 \mu \mathrm{m}$. Figs. 15 and 16. Transversely sectioned appendage composed of an electron-dense core (DC) surrounded by a thick electron-transparent matrix (TM). The ascospore wall comprises an electron-dense episporium (E) and an electron-transparent mesosporium (M).

Scale bars $=0.1 \mu \mathrm{m}$.

Table 1. Comparisons of all freshwater Halosarpheia species.

\begin{tabular}{|c|c|c|c|c|c|}
\hline & $\begin{array}{l}\text { H. aquatica } \\
\text { Freshwater }\end{array}$ & $\begin{array}{l}\text { H. aquadulcis } \\
\text { Freshwater }\end{array}$ & $\begin{array}{l}\text { H. lotica } \\
\text { Freshwater }\end{array}$ & $\begin{array}{l}H . \text { retorquens } \\
\text { Freshwater and marine }\end{array}$ & $\begin{array}{l}\text { H. heteroguttulata } \\
\text { Freshwater }\end{array}$ \\
\hline Ascus size $(\mu \mathrm{m})$ & $56 \times 30$ & $80-130 \times 20-26$ & $86-137 \times 34-43$ & $53-144 \times 14.4-24$ & Unknown \\
\hline Ascospore size $(\mu \mathrm{m})$ & $33.5-64 \times 7-10$ & $26.1-35.5 \times 9.5-12$ & $26.4-38.4 \times 9.6-14.4$ & $20.4-33.6 \times 7-10.8$ & $27-37 \times 9-17.5$ \\
\hline $\begin{array}{l}\text { Ascospore guttules } \\
\text { deposition }\end{array}$ & $\begin{array}{l}\text { Numerous small } \\
\text { guttules in } \\
\text { each cell }\end{array}$ & $\begin{array}{l}\text { One large guttule in } \\
\text { each cell with small } \\
\text { guttules at the apices } \\
\text { and near the septum }\end{array}$ & $\begin{array}{l}\text { One large guttule in } \\
\text { each cell with } \\
\text { small guttules at } \\
\text { the apices and } \\
\text { near the septum }\end{array}$ & $\begin{array}{l}\text { One large guttule in } \\
\text { each cell with } \\
\text { small guttules at } \\
\text { the apices and near } \\
\text { the septum }\end{array}$ & $\begin{array}{l}\text { One or two large } \\
\text { guttule(s) in the } \\
\text { polar cell and } \\
\text { numerous small } \\
\text { guttules in the } \\
\text { basal cell }\end{array}$ \\
\hline
\end{tabular}

spores of Halosarpheia differs among species. Most species possess one large guttule in each cell with small guttules at the apices and near the midseptum, e.g., H. lotica and Halosarpheia retorquens Shearer \& Crane (Shearer 1984; Shearer and Crane 1980). However, smaller guttules are present throughout the whole ascospore in $H$. aquatica (Hyde 1992b). Little is known of the function and significance of the guttules.

A synopsis of the characteristics of all freshwater Halosarpheia species is given in Table 1 . Ascospores of $H$. heterogutulata are similar to those of $H$. aquadulcis at the TEM level (Hsieh et al. 1995). Their common characters including a thin electron-dense episporium and a thick electrontransparent mesosporium. The electron density of the mesosporium increases at the ascospore tip where the appendage emerges, and the appendage is derived from the mesosporium through a discontinuity (pore) of the episporium. This appendage ontogeny type is similar to those described in marine Halosarpheia species (Jones 1995). Unlike $H$. aquadulcis and other marine Halosarpheia species, $H$. heteroguttulata has asymmetrically organized guttules in the ascospores.

The coiled, polar appendages of the ascospore and their unfurling process in species of Halosarpheia have been studied extensively and described with SEM and (or) TEM micrographs (Baker 1991; Farrant 1986; Jones and Moss 1978, 1980; Moss 1990; Shearer and Crane 1980; Yusoff 1991). Uncoiling of this hamate appendage in water results in a long and sticky filamentous thread. The unfurled filament extends and becomes thinner. In addition to Halosarpheia species, ascospores that possess long, unfurling, polar appendages are common in other freshwater ascomycetes, e.g., Aniptodera chesapeakensis Shearer \& Miller (Shearer and Crane 1980; Shearer and Miller 1977), Annulatascus bipolaris Hyde (Hyde 1992a), and the marine ascomycetes, e.g., Tirispora unicaudata E.B.G. Jones \& Vrijmoed (Jones et al. 1994). This appendage type may provide the ascospores with a flexible and effective means for entrapment and attachment to substrata and may be an important morphological adaptation for life in fast-flowing rivers or in the sea.

Although the unfurling process in Halosarpheia species have been extensively studied, the question of how the coiled appendage is prevented from sticking together has not been considered and is still unresolved. In the TEM, the mature ascospores of Halosarpheia heterogutulata and a marine Halosarpheia species (Yusoff 1991) fixed with glutaraldehyde-osmium with added ruthenium red, comprise a highly coiled and folded filamentous appendage (electrondense) surrounded by thick electron-transparent zones. Is this electron-transparent zone a "space" or an electrontransparent coating of the filament? The answer awaits further ultrastructural studies. Hsieh et al. (1995) fixed the ascospores of $H$. aquadulcis using potassium permanganate and showed that the polar appendages were amorphous and electron dense throughout without any electron-transparent zones. This implies the electron-transparent zones observed in the appendages of $H$. heteroguttulata are compact and there may be some kind of electon-transparent gel matrix. From SEM micrographs, the part of the appendage that is adpressed to the polycarbonate membrane is much thinner than the part close to the ascospore tip. In addition, these thicker strands are never attached to the membrane. Therefore, the electron-transparent gel matrix may be nonsticky and soluble in nature, "insulate" the sticky filaments (electron-dense core), and prevent clumping before unravelling. Once in water, this nonsticky coating may dissolve and allow the sticky filaments to unravel. 

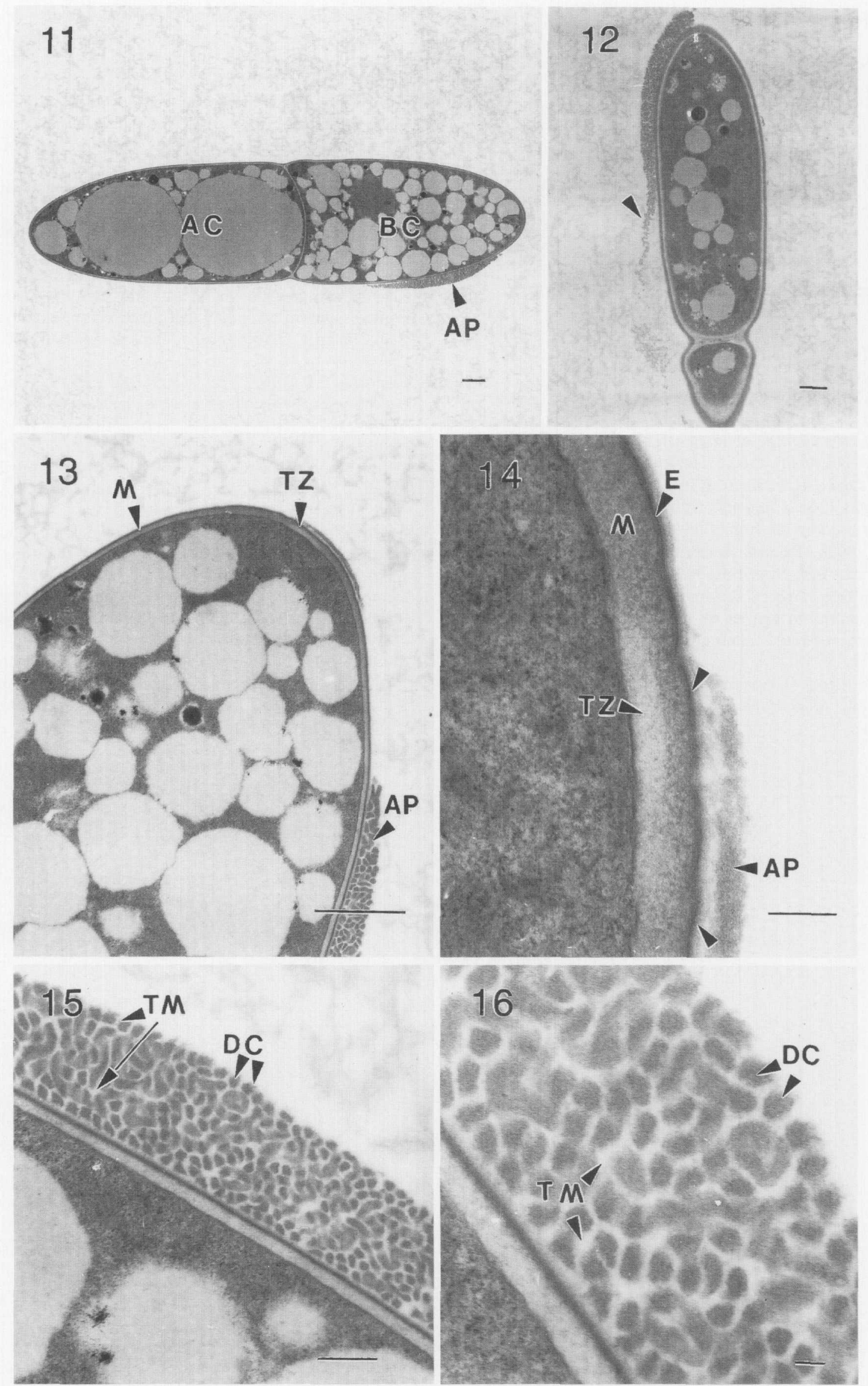

(C) 1998 NRC Canada 


\section{Acknowledgements}

Y.C. Mok, W.S. Lee, and S.L. Wong in the Electron Microscopy Unit, Queen Mary Hospital, Hong Kong, are thanked for technical assistance. S.W. Wong also thanks Dr. S.T. Moss for his teaching of electron microscopy techniques and the University of Hong Kong for a research studentship. We thank Mr. A.Y.P. Lee for photographic assistance.

\section{References}

Baker. T.A. 1991. Taxonomic studies of the Halosphaeriaceae with special reference to ultrastructure of spore ontogeny. $\mathrm{Ph} . \mathrm{D}$. thesis, Portsmouth Polytechnic. Portsmouth. U.K.

Farrant, C.A. 1986. An electron microscope study of ascus and ascospore structure in Aniptodera and Halosarpheia, Halosphaeriaceae. In The biology of marine fungi. Edited by S.T. Moss. Cambridge University Press, Cambridge. U.K. pp. 231-243.

Hsieh, S.Y., Chang. H.S., Jones, E.B.G., Read, S.J., and Moss, S.T. 1995. Halosarpheia aquadulcis $\mathrm{sp}$. nov. a new lignicolous, freshwater ascomycete from Taiwan. Mycol. Res. 99: 49-53.

Hyde, K.D. 1992a. Tropical Australian freshwater fungi. I. Some ascomycetes. Aust. Syst. Bot. 5: 109-116.

Hyde, K.D. 1992b. Tropical Australian freshwater fungi. II. Annulatascus velatispora gen. et sp. nov., A. bipolaris sp. nov., and Nais aquatica sp. nov. (Ascomycetes). Aust. Syst. Bot. 5: $117-$ 124.

Jones. E.B.G. 1995. Ultrastructure of taxonomy of the aquatic ascomycetous order Halosphaeriales. Can. J. Bot. 73(Suppl. 1): $\$ 790-\$ 801$.
Jones, E.B.G.. and Moss, S.T. 1978. Ascospore appendages of marine ascomycetes: an evaluation of appendages as taxonomic criteria. Mar. Biol. 49: 11-26.

Jones, E.B.G., and Moss, S.T. 1980. Further observations on the taxonomy of the Halosphaeriaceae. Bot. Mar. 23: 483-500.

Jones, E.B.G., Virijmoed, L.L.P., Read, S.J., and Moss. S.T. 1994. Tirispora, a new ascomycetous genus in the Halosphaeriales. Can. J. Bot. 72: 1373-1378.

Kohlmeyer, J.. and Kohlmeyer, E. 1977. Bermuda marine fungi. Trans. Br. Mycol. Soc. 68: 207-219.

Möllenhauer, H.H. 1964. Plastic embedding mixtures for use in electron microscopy. Stain Technol. 39: 111-114.

Moss, S.T. 1990. The relevance of scanning electron microscopy to the taxonomy of marine ascomycetes. In Scanning electron microscopy in taxonomy and functional morphology. Edited by D. Claugher. Oxford Science Publishers, Oxford. U.K. pp. 149170.

Reynolds, E.S. 1963. The use of lead citrate at high $\mathrm{pH}$ as an electron-opaque stain in electron microscopy. J. Cell Biol. 17: 208-212.

Shearer, C.A. 1984. A new species of Halosarpheia (Ascomycetes) from wood submerged in freshwater. Mycotaxon, 20: 505-510.

Shearer, C.A. 1993. The freshwater Ascomycetes. Nova Hedwigia, 56: $1-33$.

Shearer, C.A., and Crane, J.L. 1980. Fungi of the Chesapeake Bay and its tributaries VIII. Ascomycetes with unfurling appendages. Bot. Mar. 23: 607-615.

Shearer, C.A., and Miller, M. 1977. Fungi of the Chesapeake Bay and its tributaries. V. Aniptodera chesapeakensis gen. et sp. nov. Mycologia. 69: 1218-1223.

Yusoff, M. 1991. LItrastructural studies of ascospore appendage ontogeny in selected genera of the Halosphaeriaceae and Pleosporaceae (Ascomycotina). Ph.D. thesis, Portsmouth Polytechnic, Portsmouth, U.K. 